IRA-International Journal of Applied Sciences ISSN 2455-4499; Vol.06, Issue 02 (2017)

Institute of Research Advances

Pg. no. 62-69

https://research-advances.org/index.php/IRAJAS

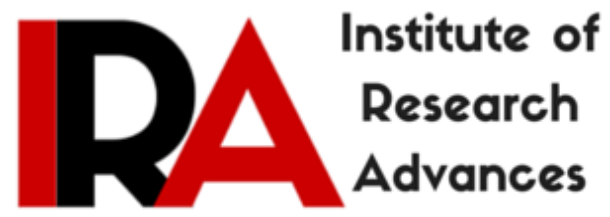

\title{
Toxicity Removal of Pulp and Paper Mill Effluent by Employing Chemicals
}

\author{
Pratibha Singh $^{1}$, Nupoor Srivastava ${ }^{2}$, R.S Jagadish ${ }^{3}$ \\ ${ }_{1,2,3}$ Department of Chemistry, \\ JSS Academy of Technical Education, Noida, U.P., India.
}

Type of Review: Peer Reviewed.

DOI: http://dx.doi.org/10.21013/jas.v6.n2.p5

\section{How to cite this paper:}

Singh, P., Srivastava, N., \& Jagadish, R. (2017). Toxicity Removal of Pulp and Paper Mill Effluent by Employing Chemicals. IRA-International Journal of Applied Sciences (ISSN 2455-4499), 6(2), 62-69. doi:http://dx.doi.org/10.21013/jas.v6.n2.p5

(C) Institute of Research Advances

\section{(cc) EY-NC}

This work is licensed under a Creative Commons Attribution-Non Commercial 4.0 International License subject to proper citation to the publication source of the work.

Disclaimer: The scholarly papers as reviewed and published by the Institute of Research Advances (IRA) are the views and opinions of their respective authors and are not the views or opinions of the IRA. The IRA disclaims of any harm or loss caused due to the published content to any party. 


\section{ABSTRACT}

Pulp and paper are manufactured from raw materials containing cellulose fibers, generally wood, recycled paper, and agricultural residues. In developing countries, about $60 \%$ of cellulose fibers originate from nonwood raw materials such as bagasse (sugar cane fibers), cereal straw, bamboo, reeds, esparto grass, jute, flax, and sisal. Large amount of toxic effluent is released during process of paper production. Pulp and paper mill spent wash (raw effluent) is highly acidic in nature with high BOD, COD, TDS, TSS, phenol, sulphate, nitrogen, phosphorus, potassium and metals viz. $\mathrm{Mn} \mathrm{Zn} \mathrm{Cu} \mathrm{Ni} \mathrm{Fe} \mathrm{and} \mathrm{Na}$. Effluent was treated with chemicals $\mathrm{FeCl}_{3}$ and $\mathrm{KMnO}_{4} . \mathrm{pH}$ was found to increase from 7.8 to 8.4 on increasing concentration $\left(1 \mathrm{gl}^{-1}\right.$ to $\left.5 \mathrm{gl}^{-1}\right)$ of $\mathrm{KMnO}_{4}$. Similarly colour, COD and BOD were decreasing with increasing concentration of $\mathrm{KMnO}_{4}$. Maximum colour, COD and BOD reduction were recorded 21.25\%, $93.79 \%$ and $81.48 \%$ respectively at $5 \mathrm{~g} \mathrm{l}^{-1}$ concentration of $\mathrm{KMnO}_{4}$. Decrease in $\mathrm{pH}$ was recorded from 3.3 to 2.0 on increasing concentration $\left(1 \mathrm{gl}^{-1}\right.$ to $\left.5 \mathrm{gl}^{-1}\right)$ of $\mathrm{FeCl}_{3}$ (Ferric chloride). Decrease in colour, $\mathrm{COD}$ and $\mathrm{BOD}$ were also observed with increasing concentration of $\mathrm{FeCl}_{3}$. Maximum colour, $\mathrm{COD}$ and BOD reduction were recorded $99.10 \%, 54.16 \%$ and $85.92 \%$ respectively at $5 \mathrm{~g} \mathrm{l}^{-1}$ conc. of $\mathrm{FeCl}_{3}$.

Key words: Pulp and Paper Mill , Chemical Treatment, Lignin

\section{INTRODUCTION}

The pulp and paper industry is huge, technically diverse, operating a wide variety of manufacturing process on a range of fibre types from tropical hard woods to straw for pulping and bleaching for paper preparation. The effluent of these industries contains stray wood chips, bits of bark, cellulose fibres, dissolved ligneous material (30-45\%), saccharinic acid (25-35\%), formic acid and acetic acid (10\%) and extractives (3-5\%). The residual lignin present in wood fibre is major colouring material, and also reacts with chlorine molecules and forms organochlorine compounds in the effluent. About $20 \%$ of the organically bound chlorine found in bleaching effluent corresponds to relatively low molecular mass (m.w 4000) products. [1]

Chlorine released after bleaching cross-reacted with lignosulphonic acid, resins, and related compounds and forms chlorinated hydroquinone, phenols, dibenzo-p-dioxin and dibenzofuran in the effluent.

These chlorinated compounds are highly toxic, mutagenic and ecoestrogens. They are partly responsible for the high oxygen demand (BOD and COD). The toxicity of a chlorinated compound increases with increasing number of chlorine atoms in the organic compound, and it is believed that polychlorinated dibenzo-p-dioxine is probably one of the most toxic compounds with an $\mathrm{LD}_{50}$ value of $1 \mu \mathrm{g} / \mathrm{kg}$ body weight is formed in the effluent of pulp and paper mill.[2]

In pulp and paper mill, 273-455 $\mathrm{m}^{3}$ of water is required per tones of paper produced that consequently generate $300 \mathrm{~m}^{3}$ as wastewater. Alkali pulp and paper mills provided with soda recovery, discharge about 270-450 liters of water per $\mathrm{kg}$ of paper with an average of $305 \mathrm{lt} / \mathrm{kg}$ and the amount of lignin discharged being $40-50 \mathrm{~g} / \mathrm{kg}$ of bleached paper produced. In a small paper mill without soda recovery, all of the black liquor (200-250 g/kg of paper made) is discharged. The pollution load in terms of biological oxygen demand (BOD) from small paper mill is 2-5 times the pollution load from large paper mills with soda recovery. The BOD load discharged per tones of paper by mills varies from $3.45 \mathrm{~kg}$ to $6.5 \mathrm{~kg}$.[3]

Effluents released by pulping and bleaching are polluting characterized by parameters unique to these wastes such as colour and organic halides (AOX). The untreated effluents from pulp and paper mills discharged into water bodies, damages the water quality. The brown colour imparted to water due to addition of effluents is detectable over long distances. The effluents have high biological and chemical oxygen demands (BOD and COD), lignin compounds and their derivatives. The dark brown colour is due to the formation of lignin degradation products during the processing of lignocellulosics from paper and pulp manufacture. The undiluted effluents are toxic to aquatic organisms and exhibit a strong mutagenic 
effect. Further more some compounds in the effluents are resistant to biodegradation and can bioaccumulate in the aquatic food chain.[4]

Earlier variouss physical chemical and biological processes have been done to remove the colour of the pulp and paper mill effluents. Physical and chemical processes are quite expensive to remove only high molecular weight chlorinated lignins, colour, toxicants, suspended solids and COD but BOD and low molecular weight compounds like alcohals, acids appreciably are not removed efficiently. [5]Present aim of study is physico-chemical analysis and identification of colour forming compounds in pulp and paper mill effluent and to assess the colour removal efficiency of pulp and paper by physical treatment using $\mathrm{FeCl}_{3}, \mathrm{KMnO}_{4}$,

\section{Materials and Methods}

\section{Location}

The study was conducted with the effluent released from Pulp and Paper mill, Chattishgarh. The factory uses cane molasses as the raw material. The efflcuent flows out into a 'nala' for about $10 \mathrm{~km}$, which passes through the villages. The villagers use this effluent for the irrigation.

\section{Sampling}

The effluent sample from the Pulp and Paper mill were collected at the main outlet point where combined effluents from the factory are being disposed of into mill influent water. Water samples at the point of discharge were collected in clean plastic container from the main outlet. The sample was collected i.e. April 2016 from pulp and paper mill, Chattishgarh. Immediately after collection the water samples were brought to the laboratory and kept in the refrigerator at $4^{0} \mathrm{C}$ till used for analysis.

\section{Analytical methods}

Electrical conductivity (EC) of the effluent was measured using a pocket type digital EC meter (Hanna Instruments Co.) calibrated at $20^{\circ} \mathrm{C}$. The reading was taken in milli siemens $\left(\mathrm{ms} \mathrm{m}^{-1}\right)$. pH of the effluent sample was measured by a pH meter (model PR 8404) using glass electrode.

For total suspend solids $100 \mathrm{ml}$ of the sample was centrifuged at $2000 \mathrm{rpm}$ for 10 minute. The supernatant was removed and the residue was washed three times by resuspending it in distilled water and recollecting by centrifugation. The residue was finally transferred quantitatively to preweighted dish (X1g). The dish was weighed again after drying $(\mathrm{X} 2 \mathrm{~g})$ to a constant weight $(\mathrm{X} 1 \mathrm{~g})$. The dish was weighed again after drying (X2g) to a constant weight at $105^{\circ} \mathrm{C}$. TSS was calculated by using the following formula.

$$
\operatorname{TSS}(\mathrm{ppm})=\frac{\left(\mathrm{X}_{2}-\mathrm{X}_{1}\right) \times 1000 \times 1000}{\mathrm{ml} \text { of sample }}
$$

The TDS was calculated as the difference between the total solids (TS) and total suspended solids (TSS), TDS (ppm), TS (ppm)-TSS (ppm).

COD and Colour unit was calculated by according to the standard method [6]. The sample was centrifuged at $1000 \mathrm{rpm}$ for 30 minutes to remove all the suspended matter. The $\mathrm{pH}$ was adjusted to 7.6 with $2 \mathrm{M} \mathrm{NaOH}$ (CppA standard method) and then used for the measurement of absorbance at $465 \mathrm{~mm}$. The absorbance values were transformed into colour unit $(\mathrm{CU})$ using the following relationship.

$$
\mathrm{CU}=500 \times \frac{\mathrm{A}_{2}}{\mathrm{~A}_{2}}
$$

where

$\mathrm{A}_{1}=$ Absorbance of $500 \mathrm{cu}$ platinum cobalt standard solution $\left(\mathrm{A}_{405}=0.132\right)$ and $\mathrm{A}_{2}=$ Absorbance of the effluent sample [6] 


\section{Effects of different chemicals on pulp and paper mill individually and in combination}

Three sets of three $100 \mathrm{ml}$ sterilized Erlenmeyer flasks were filled with $50 \mathrm{ml}$ of sample effluent. In one set of flask $\mathrm{Al}_{2}\left(\mathrm{SO}_{4}\right)_{3}$ was added at the rate of each $1 \mathrm{~g} / \mathrm{l}, 2 \mathrm{~g} / \mathrm{l}$ and $5 \mathrm{~g} / \mathrm{l}$ whilst in second set $\mathrm{KMnO}_{4}$ was added at the rate of $1 \mathrm{~g} / \mathrm{l}, 2 \mathrm{~g} / \mathrm{l}$ and $5 \mathrm{~g} / \mathrm{l}$. The entire flasks were shaken at $150 \mathrm{rpm}$ and $25^{\circ} \mathrm{C}$ for $2 \mathrm{hrs}$. Thereafter, all the samples were centrifuged at $5000 \mathrm{rpm}$ for $10 \mathrm{~min}$. After that $\mathrm{pH}$, EC, TSS TDS, COD and colour were measured.

\section{Results}

Pulp and paper mill Effluent was collected i.e. April 2016 from Pulp and Paper mill, Chattishgarh. The physico chemical analysis of spent wash (raw effluent) was highly acidic in nature with high BOD (32000 ppm), COD (45000 ppm), TDS (9566.66 ppm), TSS (97686.66 ppm), phenol (5.1ppm), sulphate (3800 ppm), nitrogen (299 ppm), phosphorus (767.66 ppm), potassium (481.33 ppm) and low content (Table 1). Raw pulp and paper mill effluent contains metal viz. Mn (3.68 ppm), Zn (3.781 ppm), Cu (0.31ppm), Ni $(0.86 \mathrm{ppm}) \mathrm{Fe}(72.07 \mathrm{ppm})$ and $\mathrm{Na}(498 \mathrm{ppm})$. However, the $\mathrm{pH}$ of treated pulp and paper mill effluent was acidic and other parameters including metals were high in comparison of MINAS value. Physiochemical characteristics were analyzed and the data are given in Table 1.

The colour of the effluent was dark brown and colour unit was recorded $6287.87 \mathrm{CU}$, whilst $\mathrm{pH}$ was in acidic range 5.1, (Table 4.1, Plate No. 1). The biochemical oxygen demand (32000 $\mathrm{mg} \mathrm{l}^{-1}$ ) and chemical oxygen demand (45000 $\mathrm{mg} \mathrm{l}^{-1}$ ) were also recorded.The pulp and paper mill also contained a good amount of $\mathrm{N}, \mathrm{P}$ and $\mathrm{K}$ and chlorine content (Table 1)

From Table 4, $\mathrm{pH}$ was found to increase from 7.8 to 8.4 on increasing concentration $\left(1 \mathrm{gl}^{-1}\right.$ to $\left.5 \mathrm{gl}^{-1}\right)$ of $\mathrm{KMnO}_{4}$. Similarly colour, COD and BOD were decreasing with increasing concentration of $\mathrm{KMnO}_{4}$. Maximum colour, COD and BOD reduction were recorded $21.25 \%, 93.79 \%$ and $81.48 \%$ respectively at $5 \mathrm{~g}^{-1}$ concentration of $\mathrm{KMnO}_{4}$ (Table 2, Plate No. 1).

From Table 3, Decrease in $\mathrm{pH}$ was recorded from 3.3 to 2.0 on increasing concentration $\left(1 \mathrm{gl}^{-1}\right.$ to $\left.5 \mathrm{gl}^{-1}\right)$ of $\mathrm{FeCl}_{3}$ (Ferric chloride). Decrease in colour, $\mathrm{COD}$ and BOD were also observed with increasing concentration of $\mathrm{FeCl}_{3}$. Maximum colour, $\mathrm{COD}$ and BOD reduction were recorded $99.10 \%, 54.16 \%$ and $85.92 \%$ respectively at $5 \mathrm{~g} \mathrm{l}^{-1}$ conc. of $\mathrm{FeCl}_{3}$ (Table 3). 
Table 1

Physico Chemical Analysis of Pulp and Paper Mill Effluent

\begin{tabular}{|c|c|}
\hline Parameters & Mean value \\
\hline BOD & $32000 \pm(577.35)$ \\
\hline COD & $45000( \pm 946.48)$ \\
\hline Nitrogen & $299( \pm 9.46)$ \\
\hline Phenolic compounds & $5.1( \pm 0.06)$ \\
\hline Phosphorus & $767.66( \pm 26.26)$ \\
\hline Sulphate & $3800( \pm 57.73)$ \\
\hline Total suspended solids (TSS) & $97686.66( \pm 566.10)$ \\
\hline Total dissolved solids (TDS) & $9,566.66( \pm 88.19)$ \\
\hline Chlorine & $2800( \pm 26.83)$ \\
\hline Colour & $6287.87( \pm 97.85)$ \\
\hline Total organic carbon & $2880( \pm 22.30)$ \\
\hline $\mathrm{K}$ & $481.33( \pm 28.93)$ \\
\hline $\mathrm{Na}$ & $498( \pm 16.83)$ \\
\hline $\mathrm{Cu}$ & $0.31( \pm 0.03)$ \\
\hline $\mathrm{Fe}$ & $72.07( \pm 12.76)$ \\
\hline $\mathrm{Mn}$ & $3.68( \pm 0.64)$ \\
\hline $\mathrm{Ni}$ & $0.86 \quad( \pm 0.01)$ \\
\hline $\mathrm{Zn}$ & $3.781( \pm 0.06)$ \\
\hline
\end{tabular}

All the values are in ppm means $(n=3) \pm$ standard error. 
Table 2

Effect of $\mathrm{KMnO}_{4}$ on pH, CU, COD and BOD of the pulp and paper effluent

\begin{tabular}{|c|c|c|c|}
\hline $\begin{array}{l}\text { Conc. Of } \mathrm{KMnO}_{4} / \\
\text { Parameters }\end{array}$ & $\operatorname{lg~l^{-1}}$ & $3 \mathrm{~g} \mathrm{l}^{-1}$ & $5 \mathbf{g l}^{-1}$ \\
\hline $\mathrm{pH}$ & $7.8 \pm 0.34$ & $8.1 \pm 0.17$ & $8.4 \pm 0.11$ \\
\hline $\mathrm{CU}$ & $\begin{array}{c}5835.47 \pm 1347.57 \\
(7.19 \%)\end{array}$ & $\begin{array}{c}5005.44 \pm 634.06 \\
(20.39 \%)\end{array}$ & $\begin{array}{r}4951.40 \pm 557.38 \\
(21.25 \%)\end{array}$ \\
\hline $\mathrm{COD}\left(\mathrm{mgl}^{-1}\right)$ & $\begin{array}{c}28400 \pm 2338.80 \\
(11.25 \%)\end{array}$ & $\begin{array}{c}23866.66 \pm 2808.51 \\
(25.41 \%)\end{array}$ & $\begin{array}{c}1986.66 \pm 2313.96 \\
(93.79 \%)\end{array}$ \\
\hline $\begin{array}{l}\mathrm{BOD} \\
\left(\mathrm{mgl}^{-1}\right)\end{array}$ & $\begin{array}{c}17666.66 \pm 881.91 \\
(60.74 \%)\end{array}$ & $\begin{array}{c}12000 \pm 2390.40 \\
(73.33 \%)\end{array}$ & $\begin{array}{c}8333.33 \pm 1452.96 \\
(81.48 \%)\end{array}$ \\
\hline
\end{tabular}

Table 3

Effect of $\mathrm{FeCl}_{3}$ on $\mathrm{pH}, \mathrm{CU}, \mathrm{COD}$ and $\mathrm{BOD}$ of the pulp and paper effluent

\begin{tabular}{|c|c|c|c|}
\hline $\begin{array}{c}\text { Conc. Of } \mathrm{FeCl}_{3} / \\
\text { Parameters }\end{array}$ & $\operatorname{lgl^{-1}}$ & $3 \mathrm{~g} \mathrm{I}^{-1}$ & $5 \mathrm{gl}^{-1}$ \\
\hline $\mathrm{PH}$ & $3.3 \pm 0.31$ & $2.3 \pm 0.57$ & $2.0 \pm 0.15$ \\
\hline $\mathrm{CU}$ & $\begin{array}{c}123.73 \pm 34.87 \\
(98.03 \%)\end{array}$ & $\begin{array}{c}134.24 \pm 15.27 \\
(97.86 \%)\end{array}$ & $\begin{array}{c}56.16 \pm 4.00 \\
(99.10 \%)\end{array}$ \\
\hline COD $\quad\left(\mathrm{mgl}^{-1}\right)$ & $\begin{array}{c}22666.66 \pm 4745.68 \\
(29.16 \%)\end{array}$ & $\begin{array}{c}16000 \pm 1454.70 \\
(50 \%)\end{array}$ & $\begin{array}{c}14666.66 \pm 1763.83 \\
(54.16 \%)\end{array}$ \\
\hline $\begin{array}{l}\text { BOD } \\
\left(\mathrm{mgl}^{-1}\right)\end{array}$ & $\begin{array}{c}14000 \pm 881.91 \\
(68.88 \%)\end{array}$ & $\begin{array}{c}10666.6 \pm 2309.40 \\
(76.29 \%)\end{array}$ & $\begin{array}{c}6333.33 \pm 1452.66 \\
(85.92 \%)\end{array}$ \\
\hline
\end{tabular}

All the values are in ppm mean $(n=3) \pm$ standard error

Significant correlation can be seen between colour unit, COD and BOD of the effluent. The result of the study also supports the findings of this study. Linear relationships amongst these parameters were observed $[7,8,9]$. Most of these parameters are found to exceed beyond permissible limit and warrants treatment. The pattern of colour removal by chloride and sulphate salts of aluminium and iron were more or less similar. Per milli equivalent of metal ion for coagulation is based on percentage colour removal. $[10,11,12]$

It was observed that ferrous sulphate alone was not effective in reducing the colour of effluent as it does not form floe with pulp and paper mill waste water. The other flocculant i.e. alum, ferric chloride, lime were found effective for colour removal. But these chemicals also depend on the $\mathrm{pH}$ of the waste water. 
Ferrous sulphate in combination with alum was effective to some extent in reducing colour of effluent due to producing of more acidic chemicals. While COD reduction is comparatively lower. $[13,14,15]$

Thus, initial $\mathrm{pH}$, molecular size and electrical charge have profound influence on the efficiency of colour removal and the chemical dosage required. The coagulant dose required to maximum colour removal was $5000-7000 \mathrm{mg} / \mathrm{l}$ in case of ferric chloride and almost double $(12000 \mathrm{mg} / \mathrm{l})$ in case of alum. In all cases, colour removal decreased beyond coagulant level (optimum coagulant dose). Percentage colour removal was significantly higher in the case of treated pulp and paper mill waste. [16]

Colour causing substances present in pulp and paper mill waste are microcolloids which are hydrophilic in nature like proteins and other biopolymers. Stability of these colloids depends mainly on the hydration shell and high concentrations of colloids naturally required to withdraw the solvent from the hydration shell. [17]

Potassium permanganate, hydrogen peroxide and bleaching powder were screened for removal of calcium from raw and treated pulp and paper mill waste. Only potassium permanganate and bleaching powder yielded good removal. Highest colour removal was attained $78 \%$, the reduction in COD was of the order of $25-30 \%$ only. Similar results of $80 \%$ colour removal and $36 \%$ and 32\% COD and BOD reduction from sugar fermentation process waste water by oxidation with chloride gas were reported by Swamy et al. [18.19]

Potassisum permanganate react with a variety of organic substances which results in a net transfer of an oxygen atom from the manganate ion to the organic substrate. It has been reported that oxidation of organic compounds by potassium permangnate rarely results in complete destruction of molecule. It may, therefore, be inferred that chemical oxidation of colour causing substances results in chromophoric group rather than complete degradation of colour causing substances $\mathrm{H}_{2} \mathrm{O}_{2}$, Alum, other chemicals show similar reaction mechanism as $\mathrm{KMnO}_{4} \cdot[20]$

\section{CONCLUSION}

Many process changes have been implemented or are being considered to reduce the formation of AOX and chlorinated phenols from chemical pulp bleaching operations. There are also possibilities for treatment of effluents with microorganisms and enzymes to remove or dechlorinate organic material. Each option discussed has inherent advantages and disadvantages with regard to capital cost, operating cost, ease of profit, fabrication and installation time. Impact on other mill unit operations is also considered in choosing the best options. Many factors have to be considered in choosing an effective and economical bleaching/ treatment process that meets all the environmental guidelines. It appears that the only long-term solution will probably be to develop the technology which will allow mills to operate with zero effluent.

\section{REFERENCES}

1. Bajpai, P., Mehna, A and Bajapi, P.K. 1993. Decolorization of Kraft bleach plant effluent with white rot fungus Tramaetes versicolor. Process Biochem. 28: 377-384.

2. Binkley, W.A. and Wolfrom, M.L. 1983. Composition of cane juice and cane final molasses. Ad in Carbohydrate Chemistry, 8, 291. Ed. C.S. Hundson and M.L. Wolform. Academic Press Inc. Publ., New York, USA.

3. Chandra, R. 1996. Biodegradation of pulp and paper mill effluent Isolation and characteristics of microbial consortium. IJEP. 16: 352-355.

4. Fahy, V., Fitzgibbon,F.J., Mcmullan, G., Singh D. and Merchant, R. 1997. Decolorization of molasses spent wash by Phanerochaete chrysosporium. Biotechnol. Lett., 19 : 97-99.

5. Hashino,K. and Minorou, Y. 1980. Decolorization of industrial waste water, Japan Kokai Tokkyo Koho, 80, 132, 696 (1980). Cited from Chem. Abstr. 94: 70812. 
6. Hattori, Y., Kawabata, S, and Matsuda, T. 1977. Decolouring by activated charcoal microcapsules. Sokuhin Sangyo Senta Gyutso Kenkyu Kokaku, 1, 133, cited from Chem., Abstr, 88: 116719 (1978).

7. Idaka, E. and Ogawa, Y. 1978. Degradation of azo compounds by Aeromonas hydrophila var. 2413. J. Soc. Dyers, Coloursits. 94: 91-94.

8. Joshi, R.D. and Kapandnis, B.P. 1992. Pre-treatment of pulp and paper mill spent wash for bioenrichment with dinitrogen fixers. Biol. Ind., 3: 65-70.

9. Lafond, R.A. and Ferguson, J.F. 1991. Tappi Proc. 1991. Environ. Conf. P. 797.

10. Leach, J.M. Muellar, J.C. and Walden, C.G. 1997. CPAR Report No. 408-2, Canada Forestry Service, Ottawa, Canada.

11. Livernoche, D., Jurasek, L., Desrochens, M. and Dorica, J. 1983, Biotechnol. Bioeng. 25: 2058.

12. Modi, D.R., Chandra, H. and Garg, S.K. 1998. Decolorization of bagasse based paper mill effluent by the white rot fungus Trametes versicolor. Biores. Techol., $66: 79-81$.

13. Nandan, R.V., Todwalkare and Roy, P.K. 1990. Biomethanation of spent wash. Heavy metal inhibition of methanogenesis in synthetic medium. J. Ferment. Bioengg. 69: 276-281.

14. Patil, N.B. and Kapadnis, B.P. 1996. Decolorization of melanoidin pigment from pulp and paper mill spent wash. Indian J. Environ. Hlth. 37: 81-87.

15. Rao, T.D. and Viraraghavan, T. 1985. Treatment of pulp and paper mill waste water (spent wash). Indian experience. Proc. $40^{\text {th }}$ Purdue Ind. Waste Conf. Purdue Univ. Indiana, USA.

16. Vaidyanathan, R., Meenambal, T. and Gokuldas, K. (1995. Biokinetic coefficients for the design of two stage anaerobic digester to treat pulp and paper mill waste. Indian J. Environ. Hlth. 37 (4): 237-242.

17. Yin, C.F., Joyce, T.W. and Chang, H.M. 1989. In : Proc. Industrial Waste Conf. Purdue Univ.

18. Singh, P., Katiyar, D.., Singh A., Gupta, M .2011"Removal of Pollutants from Pulp and Paper mill effluent by Anaerobic and aerobic treatment in Pilot scale bioreactor" Int. J. of Environ and Waste management. 7 (3-4), 423-431

19. N. Kumara Swamy, Singh, P and Indira P.Sarethy.2012. Color and phenols removal from paper mill effluent by sequential treatment using ferric chloride and Pseudomonas putida Intl $\mathrm{J}$ Pharm Biosci 3 (2), 380-392

20. N. Kumara Swamy, Pratibha Singh Indira P.Sarethy, 2016, Effect of sequential treatment of paper industry wastewater using aluminum chloride and Pseudomonas putida, Indian journal of advances in chemical sciences, 226-229 